\title{
Gekko and black swans: Finance theory in UK undergraduate curricula
}

\author{
Geeta Lakshmi \\ Lincoln Business School, University of Lincoln, Brayford Pool, Lincoln LN6 7TS, UK
}

\section{A R T I C L E I N F O}

\section{Article history:}

Received 31 July 2014

Received in revised form 16 December 2015

Accepted 19 January 2016

Available online $\mathrm{xxx}$

\section{Keywords:}

Finance

Sustainability

Accounting education

Critical

\begin{abstract}
A B S T R A C T
Despite the current financial crisis, accounting and finance programmes in UK have remained popular. Finance undergraduate teaching in accounting degrees is a significant component of the degree and relies heavily on Modern Finance Theory (MFT). Some of the developments in the finance curricula are critically examined. It is argued that current finance education should become more reflective and more heterodox in approach as the current curricula is biased towards techniques based on neoclassical theory. Suggestions are given for improvement of the curricula which will allow the narrow assumptions of neoclassical theory to be widened. These involve students taking into account not only the structures and patterns of finance but also the processes which are created by human experiences as part of their interactions as well as what helps to make these processes sustainable.
\end{abstract}

(c) 2016 Elsevier Ltd. All rights reserved.

\section{Introduction}

Much has been critiqued about accountancy education (see, for e.g. Gray \& Collison, 2002; Mathews, 2001), yet relatively little reflection exists about the nature of finance pedagogy. Although accounting and finance courses have grown in popularity, the curricula appear to remain technical (Lakshmi, 2013; Pan \& Perera, 2012). A confluence of factors makes it currently vital to critically examine finance education: financial crises and the furore in the financial and accounting sectors have had major social and economic impact. It is desirable but debatable whether UK business schools, in their current state, have the capability to prepare students to deal with these economic challenges (Laing, 2012). In an era of increased competition and globalisation, graduates face a challenging scenario and must be equipped with a relevant knowledge base and critical skills (Pan \& Perera, 2012; Lakshmi, 2013). It would be prudent for institutions to reflect on their subject offerings, differentiate themselves from their competitors and become central actors in economic changes (Laing, 2012) as they too are undergoing structural changes.

In most western countries, weaknesses due to a focus on financialisation ${ }^{1}$ and business tools rather than on their responsible use resulted in a legacy of sluggish growth and recessionary pressures (Bogle, 2008; Sikka, 2015; Sullivan, 2009). This generally is considered the main cause of the 2008 financial crisis. Banks started to adopt poor lending practices and invested in toxic assets (Blundell-Wignall, Atkinson, \& Se, 2009). The sector has also been accused of malpractices, an exorbitant bonus culture and irresponsible attitude (BBC, 2012; BBC 2, 2013; Bell \& Reenen, 2014; Carney, 2014). The UK Financial Ombudsman reported a $92 \%$ rise in one year in consumer complaints reflecting the public's mistrust of the sector

E-mail address: glakshmi@lincoln.ac.uk (G. Lakshmi).

${ }^{1}$ Financialisation refers to the increase size and importance of the financial services sector which dominates the economy. 
(BBC, 2013). Along with banks, other major financial actors have also contributed to current problems-Ponzi schemes (Perri \& Brody, 2011) and accountancy firms being complicit with tax evasion practices (Sikka, 2010, 2015) have been making headlines along with insider trading. Unlike previous political or economic crises, this crisis directly involved finance professionals (Hopwood, 2009) and it is unclear why risk assessment and management systems were not more robust. The US Securities \& Exchange Commision (2013) notes that 'Over the last three years, the SEC has filed more insider trading actions (168 total) than in any three-year period in the agency's history. These insider trading actions were filed against nearly 400 individuals and entities with illicit profits or losses avoided totalling approximately $\$ 600$ million. Many of these actions involved financial professionals, hedge fund managers, corporate insiders, and attorneys who unlawfully traded on material nonpublic information, undermining the level playing field that is fundamental to the integrity and fair functioning of the capital markets.' The sheer scale of the resulting chaos has caught many by surprise-including royalty. In November 2008, Queen Elizabeth II asked academics in London School of Economics (LSE) (2015) why no one anticipated the degree of the credit crisis and was told that the theoretical tenets of market efficiency had not been disputed and system complexity had not been anticipated by academics. The conditions that ultimately caused the financial crisis were discussed by Taleb (2010) who termed them as a black swan event, i.e. rare events that were pronounced unlikely as they were perceived as outliers-but in hindsight appear perfectly normal and have far reaching consequences. Taleb (2010) cautions that many systems in society appear robust but have black swans (as opposed to the common white swans) built in, a fact which academia ignores. As a thinking profession, education should pay attention to these outliers as their consequences have a major impact on society.

The UK has one of the largest financial systems in the world (Andersson, Lee, Theodosopoulos, Yin, \& Haslam, 2014) and is also a global player in higher education (Killingley, 2012). However, overdependence on the financial sector and a weak economy impacted negatively on public funding including in the higher education sector. ${ }^{2}$ Funding for university places will now be provided by students themselves as beneficiaries of education, instead of via public grants (Browne, 2010). The sector is also undergoing other new challenges (Killingley, 2012). This has, however, not impacted too negatively on demand for accountancy and finance places. Formal finance education in the UK is imparted through business schools from UK universities, colleges or professionally accredited through accounting bodies. As a profession, the area of accounting and finance has acquired the status of one of the top professions as part of the ongoing changes of the UK economy. Related undergraduate degrees are often considered an important step towards the path of acquiring professional qualifications, although professional qualification awarding bodies, by themselves, do not demand a degree.

The overall aim of the article is to contribute to the discussion of the finance area of education. Several authors, such as Hopwood (2009) note that finance colleagues have not reflected critically on their subject. Rather than by focussing on what impedes change in the discipline of finance (Gendron \& Smith-Lacroix, 2013), this paper aims to contribute by reporting deficiencies in the way topics of knowledge and research are chosen and dealt with in the classroom. The next section, Section 2, describes briefly the provision of finance teaching in U.K. universities in undergraduate accountancy programmes. Section 3 analyses the current taught subject of finance by examining its characteristics. Subsequently, it is critiqued using some theoretical literature that the subject area has developed over time but is presently narrowly incorporated in the curricula. Section 4 proposes suggestions for improvements using principles developed by Capra (2005). The last section concludes.

\section{The provision of finance in UK universities}

Universities in the UK have been used to advance social mobility, provide quality education and research and to play a broader socio-economic and cultural role. They aim to be gatekeepers of opportunity and the main pathways into professional careers, including accountancy. UK universities have enjoyed high esteem and compete favourably with others in the global university rankings: Exeter, Leeds, Birmingham and LSE for example, feature in the top 200 world-class universities (The Guardian, 2015a). They and others are a universally powerful medium in opening doors to privilege, position, remuneration and power and also influence the public landscape through research and alumni. Historically, the UK University system has been well established, highly regulated and expanded quickly in recent years. It comprises of bodies such as the Russell Group (2014), i.e. 24 internationally recognized universities with an emphasis on strong research, teaching and practice as well as newer entrants that have become universities over the last century. University rankings are regularly published periodically in the press. The sector has gradually moved towards a quasi-market structure; most recently in 2010, English universities adopted a variable fee (almost tripling the original) with an onus on customer choice and student satisfaction (Browne, 2010). Critics claim that these moves also signalled the commodification of education (Brown \& Carasso, 2013). Other shifts in higher education include new restrictive immigration rules and changing global economics (Killingley, 2012). In short, the sector is facing challenges but there are also opportunities (Laing, 2012).

One such growing area is the subject of accounting and finance. The following table shows the students enrolled during the past few years in UK universities in this area (Table 1 ).

Despite the economic downturn that hit the UK in 2008 and the increase in University fees, both undergraduate and postgraduate student numbers have increased with a $6.07 \%$ growth rate in accounting degrees in 2010/11 over the previous

\footnotetext{
2 The privatisation of higher education had commenced earlier but the timing of the review was most likely influenced by current events. Also see Brown and Carasso (2013).
} 
Table 1

Students enrolled in degrees by year.

\begin{tabular}{|c|c|c|c|c|c|c|}
\hline \multirow[b]{2}{*}{ Years } & \multicolumn{3}{|c|}{ Undergraduate } & \multicolumn{3}{|c|}{ Postgraduate } \\
\hline & $2009 / 10$ & $2010 / 11$ & $2011 / 12$ & $2009 / 10$ & $2010 / 11$ & $2011 / 12$ \\
\hline Accounting & 24960 & 26475 & 30015 & 2475 & 2820 & 3110 \\
\hline Finance & 12185 & 12840 & 14860 & 9980 & 11025 & 13440 \\
\hline Total & 37145 & 39315 & 44875 & 12455 & 13845 & 16550 \\
\hline
\end{tabular}

Source: Calculated from UCAS (2013).

year and a higher growth rate of $13.37 \%$ in $2011 / 12$, partly in anticipation of the raised fees in $2012 / 13$. The finance degrees have shown a similar rise of $5.38 \%$ in $2010 / 11$ and $15.73 \%$ in $2011 / 12$, while the postgraduate picture shows an $11.16 \%$ increase in 2010/11 and 19.53\% in 2011/12 for the total numbers in both. According to UCAS (2015) there are over 100 U.K universities which offer either accountancy (single or jointly) or accountancy and finance at undergraduate level-these degrees have a significant portion of teaching devoted to, on average, two compulsory finance modules (Lakshmi, 2013).

A closer look at programme aims of accounting/accounting and finance in many universities for 2015 reveals module offerings of three or four years (the latter option depending on work placement in the third year). The modules vary but emphasise the subject areas outlined below ${ }^{3}$ over the study period:

Accounting and finance management, maths and statistics, law, intermediate financial accounting, management accounting, finance, economics, advanced modules in financial and management accounting and corporate finance including strategic management and options in personal development and specialisations are offered.

This listing suggests that a typical accounting degree focuses on financial accounting, management accounting and finance, i.e. "three core disciplines that are essential for a successful career in any area of business or finance" (University of Newcastle, 2015) and are supplemented with core quantitative methods, economics and organisation theory/management courses. Most institutions provide opportunities to take up business related options such as auditing, tax or a dissertation. The degree is subject specific and does not allow non-subject related options. Both Bachelors of Arts as well as Bachelors of Science versions of the degree are prevalent depending on the extent of Maths and Statistics in the programme.

The focus of the degrees is on "obtaining professional accounting qualifications prior to entering a career in business." They provide knowledge of "legal, business and social environments in which accountancy operates and enables you to be conversant in the technical languages and practices of the accounting sector in a market economy. These include measurement and disclosure in financial statements, managerial accounting, auditing, taxation, finance and business law." (University of Exeter, 2015). The importance of the degrees is emphasised through the standing of the accountancy profession. For example, the University of Leeds (2015) states: "BSc Accounting \& Finance offers you the opportunity to develop a deep understanding of the way financial information is used and managed within organisations and reported externally. Completion of BSc Accounting and Finance provides a mature understanding of the modern economy, the nature of business and the role accountancy and finance can play within it". It is thus clear that accountancy and finance are perceived to be a vital part of the modern economy and operate within a technical area with their own vocabulary.

Table 2 provides a list of topics mentioned in the curricula of compulsory finance modules taught in selected universities and professional bodies, i.e. Institute of Chartered Accountants of England and Wales (ICAEW, 2015) and Association of

Table 2

Finance topics taught in selected institutions.

\begin{tabular}{|c|c|c|c|c|c|c|c|c|c|c|}
\hline & ICAEW & ACCA & B'ham & Bristol & Exeter & Leeds & Lincoln & LSE & N'castle & Swansea \\
\hline Business, shareholder value & $\sqrt{ }$ & $\sqrt{ }$ & & & & & & & & \\
\hline Valuation techniques & & $\sqrt{ }$ & & & $\sqrt{ }$ & $\sqrt{ }$ & & & $\sqrt{ }$ & $\sqrt{ }$ \\
\hline Investment appraisal & $\sqrt{ }$ & $\sqrt{ }$ & $\sqrt{ }$ & $\sqrt{ }$ & $\sqrt{ }$ & $\sqrt{ }$ & $\sqrt{ }$ & $\sqrt{ }$ & $\sqrt{ }$ & $\sqrt{ }$ \\
\hline Capital structure & $\sqrt{ }$ & $\sqrt{ }$ & $\sqrt{ }$ & $\sqrt{ }$ & $\sqrt{ }$ & $\sqrt{ }$ & $\sqrt{ }$ & $\sqrt{ }$ & $\sqrt{ }$ & $\sqrt{ }$ \\
\hline Risk/portfolio theory & $\sqrt{ }$ & $\sqrt{ }$ & $\sqrt{ }$ & $\sqrt{ }$ & $\sqrt{ }$ & $\sqrt{ }$ & $\sqrt{ }$ & $\sqrt{ }$ & $\sqrt{ }$ & $\sqrt{ }$ \\
\hline Bonds and term structure & $\sqrt{ }$ & & $\sqrt{ }$ & $\sqrt{ }$ & & $\sqrt{ }$ & & $\sqrt{ }$ & $\sqrt{ }$ & $\sqrt{ }$ \\
\hline Sources of funds and markets & $\sqrt{ }$ & $\sqrt{ }$ & $\sqrt{ }$ & $\sqrt{ }$ & $\sqrt{ }$ & $\sqrt{ }$ & $\sqrt{ }$ & $\sqrt{ }$ & $\sqrt{ }$ & $\sqrt{ }$ \\
\hline Dividend policy & & $\sqrt{ }$ & $\sqrt{ }$ & $\sqrt{ }$ & $\sqrt{ }$ & $\sqrt{ }$ & $\sqrt{ }$ & $\sqrt{ }$ & $\sqrt{ }$ & $\sqrt{ }$ \\
\hline Working capital mgt. & $\sqrt{ }$ & $\sqrt{ }$ & $\sqrt{ }$ & $\sqrt{ }$ & $\sqrt{ }$ & $\sqrt{ }$ & $\sqrt{ }$ & $\sqrt{ }$ & $\sqrt{ }$ & $\sqrt{ }$ \\
\hline Financial engineering & $\sqrt{ }$ & $\sqrt{ }$ & $\sqrt{ }$ & $\sqrt{ }$ & $\sqrt{ }$ & $\sqrt{ }$ & $\sqrt{ }$ & $\sqrt{ }$ & $\sqrt{ }$ & \\
\hline International finance & & $\sqrt{ }$ & $\sqrt{ }$ & $\sqrt{ }$ & $\sqrt{ }$ & $\sqrt{ }$ & & $\sqrt{ }$ & $\sqrt{ }$ & \\
\hline CAPM/asset pricing & $\sqrt{ }$ & & $\sqrt{ }$ & $\sqrt{ }$ & $\sqrt{ }$ & $\sqrt{ }$ & $\sqrt{ }$ & $\sqrt{ }$ & $\sqrt{ }$ & \\
\hline Market efficiency & & $\sqrt{ }$ & $\sqrt{ }$ & $\sqrt{ }$ & $\sqrt{ }$ & $\sqrt{ }$ & $\sqrt{ }$ & $\sqrt{ }$ & $\sqrt{ }$ & $\sqrt{ }$ \\
\hline Emerging issues & & $\sqrt{ }$ & & & $\sqrt{ }$ & $\sqrt{ }$ & & $\sqrt{ }$ & & $\sqrt{ }$ \\
\hline Mergers and acquisitions & & $\sqrt{ }$ & & $\sqrt{ }$ & $\sqrt{ }$ & & & & $\sqrt{ }$ & \\
\hline Ratios & & & & $\sqrt{ }$ & & & & & & \\
\hline
\end{tabular}

Source: Compiled from module descriptors available online.

Chartered Certified Accountants (ACCA, 2015). Professional bodies provide licence to practice accountancy and permit 
exemptions from their own qualifying exams if the subject has been previously studied in a recognised institution. These two are chosen here as examples of popular professional bodies in accountancy.

The aim is to provide a number of illustrations through which the reader can get a feel for what is explicitly included in the curriculum. Accordingly, universities of various ranking whose modules descriptors were available online were chosen from the The Guardian, 2015b League Table of 96 Universities in Accounting and Finance subject area. These include the following universities (ranking in brackets): LSE (9), Exeter (28), Leeds (8), Exeter (28), Bristol (35), Birmingham (20), Newcastle (37), Lincoln (40) and Swansea (56). The topics list reported in Table 2 has been constructed by combining the named areas in professional bodies' curricula. Judgement based on subject knowledge has been used to map the areas discussed in the universities' modules against these topics.

The summary provides two insights. Firstly, certain topics such as investment appraisal (capital budgeting), sources of finance and knowledge of markets as well as the capital structure models, dividend policy models, asset pricing models, risk and portfolio theory and financial engineering (the use, design and pricing of derivatives), apparently are regarded as vital knowledge. Multiple forms of valuation, and mergers are explicitly named, but only in certain universities. Other topics are mentioned (classified under "emerging issues") such as Islamic finance, behavioural finance, ethics etc. but appear to be only sporadically available. ${ }^{4}$ Secondly, and unsurprisingly, the universities align themselves with the curriculum of the ICAEW (2015) and ACCA (2015). The latter is to be expected if the promised exemptions are to be achieved.

Similar authored texts in these universities are favoured both at introductory level such as by Atrill (2009) and also at advanced level by Brealey, Myers, and Allen (2013), Arnold, (2013), Bodie, Kane, and Marcus (2013), Hillier, Grinblatt, \& Titman (2011); Hillier, Ross, Westerfield, Jaffe, and Jordan, (2012) These texts are established with several editions. The books have changed slightly over the years to reflect case studies about globalisation and recent events but retain their core features. An electronic search into the contents of these texts fails to find any mention of finance related to more nascent forms of organisations/funding such as social enterprises, charities, community funding or crowd funding. One of the universities has stated that it is not necessary to have the latest edition of the text, older versions will do, suggesting that texts change only marginally. Suggested readings, where available, from journal articles appear to be mostly from the precrisis period other than on empirical testing and mergers. None of the readings relates to emerging issues such as social enterprises, Islamic finance or ethics, although there is a mention of "recent financial scandals" and discussion about "extent of market efficiency" in the curricula of one/two universities.

The curriculum appears largely similar in most universities in being governed by the tenets of MFT, viz. "the efficient market hypothesis (EMH), the trade-off between risk and return encapsulated in the Capital Asset Pricing Model (CAPM), the Modigliani-Miller Theorem of capital structure (M\&M) . . . (based on no arbitrage) and the Black-Scholes-Merton approach to option pricing (financial engineering)" (Miller, 2000; see also Arnott, 2005; Caldentey \& Vernengo, 2010). MFT, based on financial economics, evolves out of assumptions applied to the firm, its environment and its drivers. Its principal modus operandi is to compare testing of real life data to the theory and to puzzle over the deviants, i.e. the anomalies. As an example, LSE's module on Corporate Finance states: "We first study the empirical evidence of the CAPM and other asset pricing models, and then analyze different tests of market efficiency focusing on event studies and investment anomalies." Moreover quantitative methods are often taught in conjunction with finance as they are required in order to understand topics such as modern portfolio theory and asset pricing, risk management and derivative pricing and financial forecasting. Models and theories, such as CAPM and options theory are frequently introduced (Johnstone, 2013). This demonstrates that the focus is on neoclassical finance, which assumes: people are well-informed, independent (selfish and atomistic), rational maximisers of information sets, objectively updating expectations through mathematical algorithms. Rationality is defined in terms of consistent, transitive, monotonic and convex preferences. Utility and profits are based on objective monetary assumptions, agents are forward looking and discount the future using exponential discount functions in which inter-temporal preferences are consistent. Most importantly, people are homogenous, i.e. one model can capture all types of people (Baddeley, 2013; pp. 8-9). The curriculum thus seems to endorse the optimistic views of financial economists, such as Ross $(1987,2009)$, that "the success of (neoclassical finance) theory is the envy of the social sciences" and that the homo economicus decision maker with perfect information thinks more is better than less every time. It is assumed that given the vast quantitative data available in the field, the homo economicus is able to make optimal decisions about topics such as derivative pricing, cost of capital and asset valuations which result in shareholders' wealth maximisation (Bettis, 1983; Fromlet, 2001). Although, imperfect markets and information exist in the curriculum, there appear to be optimal ways around them (Giacalone \& Thompson, 2006). In short, the focus is on use of neoclassical theory (Findlay, 1987; Merton, 2002); Miller, 2000) and on excluding other pluralistic/sociological theories (Lee, 2012; Lee, Pham, \& Gu, 2013; Gendron \& Smith-Lacroix, 2013). Practice is based on "techniques and tools" (see for e.g. QAA 2007a; University of Sheffield, 2015) and what is emphasised is: "how to apply the value maximization principle to corporate decisions, such as investment decision, borrowing decisions, and dividend decisions." (University of Essex, 2015). MFT starts with implicit assumptions. There is no mention of how finance can benefit other non-corporate organisations such as cooperatives, charities, family businesses and social enterprises, how the homo economicus gets his information (Thaler, 2000,137) or how the financial sector impacts on the economy through intergenerational risks. Mention of ethics is rare (Giacalone \& Thompson, 2006; Boatright, 2010;

\footnotetext{
${ }^{3}$ See, for example, Universities of Exeter (2015),Bristol (2015), Newcastle (2015), Essex (2015), Sheffield (2015), Leeds (2015) and LSE (2015).

${ }^{4}$ It may be that some universities expand on these topics to supplement teaching through various other activities such as talks, videos, extra readings etc.
} 
Lakshmi, 2013) as is the concept of responsible capitalism (Carney, 2014). There is no critique of the MFT itself or a rationale for its evolution (Saito, Savoia, \& Famá, 2013), only one for individual models. It would appear that the fictional character, Gordon Gekko of the movie, Wall Street" (1987), who endorsed endless greed, reigns supreme (Krugman, 2002). MFT has been adopted as the standard paradigm - if empirical data are used to test its theories and the results do not match, these results are taken to be anomalies. The latter notion is reminiscent of black swans - which are never assumed to exist till events prove otherwise.

In short, universities appear to be imputing a similar, highly technical training set with a worrying silence on reflective and debatable issues. Given that the recent crisis has followed previous financial crises (Reinhart \& Rogoff, 2009), insider trading and unethical financial practices have been under the spotlight (BBC 2, 2013), these singularly focused curricula along with the absence of vital issues are of considerable concern (Caldentey \& Vernengo, 2010).

\section{The subject of finance}

\subsection{Development of finance}

The discretionary nature of finance and money has made its exact aims, functions and activities theoretically and practically contestable through time.

The subject has interested Marxists as well as capitalist followers and has also mutated in between the two extremes. Different critical schools of thought emerged with diverse agendas, epistemologies and responses to economic and financial challenges. UK economists, amongst them Keynes, have also been prominent agents of change and have contributed to the discussion on the critical, philosophical and discursive nature of economic and money.

The growth in finance in the second half of the last century signalled a fundamental change. There was a shift from one rooted in society and subject to one that was aspiring to be value free and "scientific" and hence independent of outside norms. The previous, more generalist view of finance and economics emanated from a broad spectrum, based on the interests of economists who were often also philosophers, political scientists and sociologists. This had made finance multifaceted and value based. With the new focus, finance became technique based and limited to a narrower foundation. Compared to other professions, such as medicine, the profession of finance concentrated itself only on the knowledge toolset and not on the appropriateness of the use of the toolset in the wider context. While mistakes in medical practice may be spotted relatively quickly, poor governance in the finance profession is relatively slow.

The Quality Assurance Agency (QAA, 2007) regulates teaching in UK universities through subject benchmarks-including one in finance ${ }^{5}$ (QAA, 2007a.) that defines finance as "an activity concerned with the workings of capital markets and the interaction between such markets and economic units, such as households, firms, financial institutions, government and overseas enterprises." As finance relates to employing capital resources to accomplish personal, corporate, business or public objective, it is closely linked to economics and accounting (QAA, 2007b, paragraph 1.4). Interestingly, it is considered a social science (QAA, 2007c, paragraph 2.2), even though the emphasis has been on value-free modelling. From economics, it takes on the mantle of arbitrage, markets, rational expectations and the homo economicus as a rational actor. Quantitative and econometric analysis is sine qua non to analyse financial relationships as prices and value of traded assets are readily available (QAA, 2007a, paragraph 3.2). Unlike economics which deals with different types of goods (assets), the assumption in finance is that financial assets are perfect substitutes; the focus is on the relationships between pricing of different financial assets (Ross, 1987). Finance is also a vital part of accounting programmes (UCAS, 2013) and uses accounting data. (QAA, 2007b).

The QAA (2007a) benchmark suggests that finance can be studied in conjunction with subjects such as languages, law etc.-with a professional, sustainable, intellectual and ethical focus (paragraphs 2.1 and 2.2). The topics (QAA, 2007a, paragraph 3.2) are numerous and encompass functional, theoretical and numerical areas.

Unlike what is suggested here, finance, in the majority of the business schools, appears being taught in a narrow, stylized manner as well as within the framework of a neo liberal paradigm. The traditional emphasis has been on the firm and its relationship with the market-there is an implicit assumption that all students will work in the future for profit only seeking listed organisations. The tension between QAA and its more liberal focus has been subsumed by the technical skill set (and silence on vital issues) offered by universities described in Section 2. It is suggested that this unnatural closure of finance should be open to debate and problematized again.

\subsection{Science of choices or choices of science?}

As described in Section 3.1, the current flavour of finance and economics in research and teaching has become increasingly scientific inquiry oriented; it champions various natural science methods (QAA, 2007b paragraph 2.2) based on assumptions that do not take into account the diversity and the variety of the social realm. In the quest for functional

\footnotetext{
5 This is under draft consultation and is subject to review. A copy of the draft consultation is available on line from the QAA website but has not been formally adopted when this article was written. Although it does not make vast changes in the subject boundaries, it suggests that ethics and the social aspects should also emphasised.
} 
decomposition, it has been reduced to atomistic modelling. Technical rationality, technical specification and technique abound. Until the 1950s, finance "was a very anecdotal based discipline" (Fox, 2010). The new academics that heralded the science-led revolution predominantly had mathematical and technical backgrounds. Suddenly, finance and economics appeared to change direction from a social science subject to one of pure science; moreover the novel idea of tingeing every activity of economics with science gave rise to the term "Economics Imperialism" (Lazear, 1999), a consequence of modernity. The availability of powerful computing and deregulation in the hands of the masses also made mechanical and technical analysis straightforward (Mishkin \& Strahan, 1999), but blind to the unintended consequences of its use. At a push of a button, one could calculate the "correct" price based on sophisticated models such as those of Black \& Scholes (1973) or compute what the implied variance in stock prices was if the option prices were held to be true. The dilemma of the chicken and egg approach (Ross, 1987) was forgotten, i.e. were prices a result of the volatility or was the former the precursor of rapidly changing dynamics? It proved easy to forget that models can only relate to some of aspects of what people do and how they live; they cannot replace them (see for e.g. Jorion, 2009 who notes that Value at Risk models in options theory can be very sensitive to inputs, i.e. much more than the processes modelled). Even if conditions hold for some time, in social sciences unlike in the natural sciences, there is no agreed period required for testing and the concept of "long run" carries no definition. Consequently, the behaviour of financial markets can come up with contradictory approximations depending upon the period of study. The penchant of using natural sciences methods, where cause and effect can be separated and of following a positivist approach, make economics feel increasingly more like a hard science that aims for control, regardless of how its results are used, even when lacking in the kind of predictability that such science is used to.

Positivism, as a logic of science, appeals to academics as it assumes neat boundaries-even though these often appear to be lacking in the real world. This prevents economics from getting results like a hard science. It also tends to ignore double hermeneutical theory (Giddens \& Dallmayr, 1982) where financial actors are not only influenced by the theory but also shape it. It has proved easy to forget, for example, that exogenous variables may easily become endogenous variables (for example, research is conducted on both equations: given the betas of stocks what were their predicted returns or given their returns what were their implied betas-only one of these, if any, can be true). Powerful theories such as CAPM had poor results presumably due to either the fact that they were excessively simple or to the fact that the correct proxies had not been found as yet (Fama \& French 2004). There was a reluctance in academic circles to choose the option of "no longer" over "not yet". In fact, library searches indicate that CAPM is still being tested in 2015, over 53 years after its inception. In contrast, Bernardi, Melton, Roberts, and Bean (2008) note that despite the growth of financial research, few papers explore the link between ethics and finance. That link has been deleted from the discipline, unlike from medicine.

The widespread use of cliometrics and model centric research along with the large number of databases and packages has made it impossible to divorce finance from quantitative research (Coleman, 2014), sometimes at the cost of excluding more interesting qualitative research. Bennis and O'Toole (2005) argue that business schools are not sufficiently grounded in social science and its problems. The imitation of research methods from the non-social sciences has not been welcomed; Cohen \& Elster (1985) discuss the classification of the sciences to argue how social sciences are distinct from natural sciences and should thus be treated differently. The intended precise and purposeful use of the results is often offset by the effort of exploring the intricacies of the paradigm and the unnecessarily complicated testing methodology (Podolny et al., 2009). There is an emerging consensus that excessive use of formal methods (even when brilliant by itself) often blinds users to the multifaceted and purposeful social reality, as expressed for example by Giddens' double hermeneutics, that makes the complicated architecture of financial models fragile (Arnott, 2005; Taleb, 2010). The propensity of economists to imitate "procedures of brilliantly successful natural sciences" and apply them to "phenomena of organised complexity" is dangerous as the "pretence of knowledge" crowds out common sense (von Hayek, 1989); social sciences are far more fluid and more difficult to generalise (Myrdal, 1972). It has not been possible to prove, for example, that financial agents behave with prescient regularity. This is ironic as the one subject that the discipline of finance has ignored and forgotten, much to its own detriment, is its history of crashes, bubbles and bank failures (Reinhart \& Rogoff, 2009). Minsky (1977) predicted in his Financial Instability theory, how markets tend to react with speculative euphoria leading to bubbles. While his theories had great insight, they were not taken seriously as they were not cast in mathematical models. However, some of them are being resurrected in light of the sub-prime crisis.

\subsection{Neoclassical approach and lack of pluralism}

The current subject of taught finance is rooted in the assumptions of rational investors, frictionless markets and shareholder wealth maximisation. While this formerly was only a convenient starting point for modelling the firm it has become the norm in most taught literature and texts in undergraduate business schools. The postulation of wealth maximisation is embedded in the ideology of utility functions and the optimal choice, which are recast as a mathematical function, but the "satisficing, bounded rationality and chunking" (rather than rational) behaviour of the individuals as pointed out by Herbert Simon in 1950s (Güth, 2010) is ignored. The behaviour of bankers who seek to protect their own bonuses often at the detriment of shareholders provides another example. Jones and Felps (2013, p. 27) analyse the utilitarian foundations of shareholder value maximisation using positive-normative triangulation and argue that it is outdated. The empirical evidence also shows that shareholder wealth maximization is not a good way to promote social welfare. Similarly, Sen (1977) is a vociferous critic of the neoclassical model. An alternative is not missing however. Ferguson (2011, p. 2) emphasises a holistic approach to financial management aligning the interests of employers and employees, sellers and consumers, issuers 
and investors. Still the idea of wealth maximisation has remained the bedrock of most finance theories connecting to technical rationality and replicability. Some texts (Arnold, 2013) discuss the objectives of the firm in terms of the stakeholders but advocate the convenience of using shareholder value to signal the objective. Moreover the theories of finance such as capital structure models rely on the existence of shareholder rationality to explore the effects of different initiatives. This may again be due to its ease in teaching rather than to its value as a link to reality. Indeed, wealth maximisation is the first axiom a student learns in the finance curriculum.

Christian and Yanis (2006) describe the three axioms of neoclassical economics, i.e. equilibrium, preferences and individualism, and then proceed to explore the aversion to pluralism they exhibit. It would be wrong, however, to state that finance/economics theory has been an inert and concretised subject. Although mainstream economics has been in existence for a number of years, heterodox economics has gained some support in recent times (Lee et al., 2013; Lee, 2012; Maio, 2013). Lee (2012, p. 339) refers to it as a

"particular group of contemporary theories aimed at explaining the social provisioning process, to economic policies recommendations predicated on the theories, and to a community of economists engaged in this theoretical and applied scientific activity. Thus, heterodox economics is not (at least for the past two decades) defined in negative, oppositional terms or as a dual to mainstream economics but as a positive alternative to it. So if mainstream economics disappeared, heterodox economics would be unaffected."

The differences between neoclassical and heterodox economics are more fully explained by Dobusch \& Kapeller (2012, Fig. 1) and as key proponents of heterodox economics, Lee et al. (2013) discuss how UK neoclassical economists are intolerant of any other paradigm.

\subsection{The individual versus the model}

Although other important areas of finance have emerged, such as behavioural finance, which attempts to understand economic behaviour and its cognitive biases without applying assumptions, these have not become part of mainstream finance, which sees itself as synonymous with corporate finance and MFT. Other areas of finance are more complex: as a departure from traditional finance, they recognise the plurality of stakeholders and motives in an organisation (Jensen, 2002). Increasingly, research papers are documenting the unexplained myopia (Sinclair, 2003) of financial agents who indulge in opportunistic behaviour (Sinclair, Spier, \& Skinner, 2008). There has been growing recognition that finance is limited in its rigid form. Minsky has criticised the development of traditional finance from four angles: role of price as signals; failure to reach equilibrium as imperfections exist; treatment of capital, i.e. the anomaly of neo classical capital versus real physical capital; and the role of savings and of money including the notion of uncertainty (Papadimitriou \& Wray, 1999) thus keeping the debate open. Of late, market psychology studies are back on the agenda and the beliefs about momentum in markets and rational investors are being examined through a new area of behavioural finance. Coleman (2014), Keasey \& Hudson (2007) and Thaler (2000) present arguments why theorists may differ from practitioners in their use of finance theory. Some behaviourists argue that one should not think of rational individuals maximising their own utility but of multiplayer economic agents such as traders operating in the market. For example, Beunza \& Stark (2012) discuss the roles of social cues on agents in shaping derivatives market activity and argue that if enough traders deviate from each other, their activity becomes resonant with reality-but also results in disasters in the trading room. This view sounds radical but echoes that of Keynes who discussed the notion of human behaviour and markets in terms of animal spirits already in 1936 (Akerlof \& Shiller, 2009). The modern notable proponents of behavioural economics and finance are Kahneman and Tversky. Baddeley (2013) describes some of their studies.

These examples show the need to bring pluralistic/heterodox approaches into main stream teaching in fuller view as the neo classical paradigm of the fully informed individual maximising wealth doesn't appear compatible with reality anymore. In curriculum terms, the QAA (2007a) itself acknowledges the wide spectrum through which the subject can be viewed.

As a subject area, finance and its actors have sometimes been labelled as immoral. The current crisis in the banking sector, exemplified by insider trading, LIBOR, commodities and exchange rate rigging and mis-selling of financial products along with the response of the bankers since 2008 (BBC 2, 2013), has enhanced the discussion on the role of finance. There is a suggestion that greed or Gekkos can be inadvertedly created.

As finance became progressively reductionist and model centric, it divorced itself from all societal norms and was dubbed like other science subjects as an amoral science, i.e. objective or value free-the notion of right nor wrong did no longer enter the equation. The argument was that in the presence of free, efficient markets, the best choice would emerge and the society would be Pareto optimal (Clark \& Schug, 2010). "Trust markets and their entrails", therefore, became a valid assumption for valuation models (Brealey \& Myers, 2003; pp. 364-365). However, from a systems thinking point of view this type of analysis ignores a) reflexive behaviour (Hines, 1989) of human beings and b) the complex nature of human interactions. The feedback loop is evidenced in real world monetary markets with large accessible datasets along with recent innovations, which have fed back into markets. MacKenzie (2005) discusses Michel Callon's performativity view of finance and points out that the topic initially controls the actors, but after a time the actors change the topic itself-exhibiting reflexive behaviour. Ferraro, Pfeffer, \& Sutton (2005) also discuss the self-fulfilling tenets of economics that make it possible to choose policies by their predicted effects. Wang, Malhotra, \& Murnighan (2011) explore how “economics education may have serious, albeit unintended consequences on our students' attitudes toward greed." (Dowd, 2004). Dowd (2004, p. 510) comments upon the abstruse 
research methodology used in business research and notes that the majority of research in "the best (or more accurately highly rated journal) produce issue after issue of research that might be correct ... to 1.5 specialists . . but has no discernible social value". This view is echoed by Bennis and O'Toole (2005).

Ghoshal \& Moran (1996) question the homo economicus' view and quote extensively from many sources to argue the negative implications relating to individual choices and their role in business theories. Ghoshal (2005) argues that the idea of a selfish opportunist is often unreal as in Milton Friedman's world individuals always have to be managed as they are selfseeking; Ghoshal (2005) cites Noreen 1998 who pointed out that this view promotes mutual mistrust on the part of the actual actors; this mistrust is mounting but also reifying and ultimately detrimental. This may explain why financial market agents mistrust their property rights and seek to transfer them through risk management strategies. Of late, academics are arguing again in favour of active intervention in the markets as they recognise these issues (Akerlof \& Shiller, 2010). Examples abound of the importance of the plurality of interests in the real world: shareholder wealth maximisation may be a simple way to derive optimum solutions, but firm failure undeniably affects not only shareholders but all stakeholders. Similarly, social networking is widely regarded as a pathway to good business, and employability. Family businesses and kinship can also be important economic models to run business and don't rely solely on one objective. Thus "deviations from self-interest have a fundamental impact on core issues in economics" (Fehr \& Fischbacher, 2002). These models based on social contract theory are currently ignored at undergraduate level.

\subsection{Assumptions}

As mentioned, it is remarkable how easily assumptions are applied to reality and may become reality when one teaches them-even when there is little supporting evidence. One may think of derivatives and options that are assumed to be important instruments to reduce credit risks. Scholes (1996) defended their use and dismissed claims that these could cause instability in markets. However, derivatives created for risk management became speculative in nature as the contract holders ignored problems of adverse selection and moral hazard. Moreover, toxic asset holdings were contagiously transferred (Jorion, 2009), through securitisation, from banks that could not even account for the totality of risk they had on their books (as derivatives contracts are subject to choice not to obligation). Haug \& Taleb (2011) and Thomsett (2013) critique and discuss how the option traders use sophisticated heuristics that they develop themselves rather than the BlackScholes-Merton formula for derivative trading (taught even though it is based on flawed assumptions and inaccurate variables). Sometimes these assumptions can prevail simply because it is expedient to do so. Another major assumption which has been questioned and on which several models are based is that of the normal distribution of prices (Bogle, 2008; Taleb, 2015).

The EMH, which is one of the key axioms of current MFT, states that all past and public (and possibly private) events are seamlessly included in market prices, the corollary being that market prices are rational beacons of their worth in terms of previous local choices. This allows daily market prices to be used as valid data and benchmarks for performance. However critics (e.g. Dempsey, 2013; Findlay \& Williams, 1987; Soufian, Forbes, \& Hudson, 2013) and the markets themselves have shown the world of people to be different-rocking and rolling periodically overshooting and spectacularly crashing. EMH had been so accepted and internalised by Robert Merton that he questioned the apparent irrationality around him when he wrote in a MIT working paper in 1985, “. . . perhaps general economists will begin to ask questions like "Why do consumption, dividends and replacement costs exhibit so little volatility when compared with rational stock prices?' (Fox, 2010). This had been echoed earlier in a paper by Marsh \& Merton (1986) when they defended EMH and the markets' excessive stock volatility. They vigorously defended the holy grail of efficient markets by stating that if markets were not efficient this would imply that "production decisions based on stock prices will lead to inefficient capital allocations." They went on to state "If the applications of the rational expectations theory to the virtually ideal conditions provided by the stock markets fails, then what confidence can economists have in its other areas of economics ...". In other words, they believed that their models of markets and their valuation are real despite evidence to the contrary. In recent times, this view has been questioned (Coleman, 2014; Findlay \& Williams, 2000). Most models in finance are theories of what theorists think the world is; not what it is and often not even of what it should be (Arnott, 2005). Milton Friedman advocated positivism and argued that models should be judged on their predictions rather than their assumptions, viz. rather than on their normative value. The reasoning was that the models used empirical data and were based on reality. Unfortunately, reality appears to be based also on people's norms. No predictions that can be used in this way have come forth, therefore-but advocating them has made clear that models and what they apply to can become confused, even for intelligent people. As Tinker, Merino, \& Neimark (1982) and Frankfurter \& McGoun (1999) noted, positive theories will mask value laden and ideological stances.

\section{An alternative approach: suggestions for improvement}

The above sections offer an overview of where the subject of finance is facing serious critique. As it is taught, the subject appears to focus on the behaviour of opportunistic agents who behave uniformly asocially as well as efficiently and effectively in theoretical and artificial environments. Current pedagogy discusses "anomalies" in the financial systems, but seldom explores why they should be classed as anomalies and not normal occurrences. Although behavioural finance (Baddeley, 2013; Thaler, 2000) deals with the experimental study of observed financial choices and decisions and uses experiments to explore biases, it appears to use a quite narrow frame to do so. The current text book knowledge is the result 
of a study of tools or of what can be treated as tools - as well as of its methods and techniques. It turns the ever-changing way in which people deal with each other into something that is sufficiently mechanical to be used as well as misused - as in the case of accountants openly supporting tax avoidance or finance professionals misselling risky products. In the short run, this may benefit the organisation, but is unsustainable.

There may be two approaches to deal with the difficulties created by such a narrow focus in finance. One is to identify the weaknesses of the curriculum and discuss and explore possible improvements. This is the approach identified by Kuhn (1962) as typical for normal science. It would seem adequate to maintain and keep teaching in finance and accountancy up to date-as long as it consciously excludes the intentionality that is characteristic of living beings. The other approach links to Kuhn's notion of revolutionary science. It allows for a regular evaluation of mistakes and for the development of an approach that includes not only the study of tools, but also the study of the human use of tools. Unfortunately, as argued in this paper, the present situation seems characterised by a relatively long and prolonged absence of improvements to either the normal or the revolutionary type. Restrictions on what is taught need to be loosened to change that situation.

This might take the form of teaching students to consider particular issues in detail, such as the positive effects that a reduction of the existing inequality of wealth might have (Sikka, 2015). It also might take the form of widening the horizon of those teaching finance and of diversifying research in terms of the areas considered, as proposed by Gendron and SmithLacroix (2013). Alternatively, finance might become a profession, analogous to medicine, and start to focus on the moral use of knowledge as well as take responsibility for its use. This development might take its cue from evaluation and concentrate on assessing the social consequences of financial interventions. Unfortunately, the drive to initiate it appears to be lacking. It is deemed useful therefore to focus in this paper on another important lever, which is that researchers in finance start to search not only for high quality of what is used, as at present, but also for high quality of the process of use, i.e high quality instructions. This would include searching for the improvement of moral values, intentions and feelings. Various alternatives have been proposed to support such searching. One would be to adapt and modify the existing approach gradually, as in the 'normal' approach, for example by starting to treat markets as embedded in society; Vollmer, Mennicken, and Preda (2009) present a literature review on the advances in sociology of finance. This would make them contextually constrained in terms of possible financial and market interventions. Capra (2005) proposes choosing a more 'revolutionary' constraint: to change to the study of 'communities' of living systems (p. 19), in particular communities of humans, who together would constitute living systems as well. It is attempted in the following to develop the latter idea, thereby to better understand what product to include in academic curricula as well as what methods to acquire it.

As Capra (2005; p. 20) notes, implementing this idea requires a 'perceptual shift'-from assuming that 'subject' and 'object' are methodologically distinct to assuming that they are not. In the latter case, subjects and objects are treated as intertwined through networks. Thus social networks which read market information become the information for third parties. Occasions to interact based on social structures, stabilises the information set allowing individuals to benefit and creates new structures. This is exemplified by studies of how one person's action is supported by the resource that another person's action provides and vice versa. All research supporting such studies takes the form of methodological instructions addressing academia (e.g. 'support two persons to interact' to mutual gain). The more such instructions are of high quality, i.e based on meaningful values, the more they can be expected to facilitate the development of a second type of high quality instruction, i.e. instructions addressing academic participants or participant instructions. Examples would include 'modify your intentions by participating in an interaction' to allow mutual support or 'maintain the interaction with others' as long as this helps the addressees to act competently. The implementation of such high quality instructions should support addressees to increase their competence-so they become able to change interactions as a way to deal with internal or external threats.

Capra (2005) argues that this alternative form research provides a way to initiate and develop sustainable societies, i.e. societies to which competent students of finance contribute more than at present. In terms of the metaphor he uses, such students should function as living subsystems of 'living systems' (p. 19, or as 'nested systems', p. 23). This requires that they no longer study things or 'parts' by themselves, but instead study how 'parts' relate to a 'whole', i.e. refocus their study to how living systems integrate their parts (2005; p. 20). This includes the (methodological) instruction to search for (participant) instructions to interact with others. The latter constitute what Capra calls 'contextual knowledge' (p. 21) as they refer to the context in which one individual's action informs the action of another by serving as its resource. Trying to acquire such knowledge implies a shift from searching for resources that show 'quantity' to searching for resources that show 'quality' from the viewpoint of the individual, or in other words, to replace the search for quantity by the search for quantity-withhigh-quality to the individual participant (p. 21). Instructions of this kind no longer specify the 'structure' of an interaction (what is usually subsumed under 'objective knowledge'), but rather how individuals are advised to act strategically to contribute to a 'process' or flow (p. 21). The resulting interaction thus creates something that allows for the internal recognition of resources as well as for an external recognition of 'patterns' of changes of the whole (p. 21). Structures are thus the result of processes and patterns, not the start of the exercise. This allows the corporate finance area to be widened to embrace diverse organisations.

Capra (2005) continues by describing the type of result that both types of instructions make possible. When people implement participant instructions he refers to each person's acts as solving his or her individual 'problems' by way of helping others to solve theirs (p. 23). The more successful each is, the more he or she contributes to the formation of 'sustainable networks' (p. 23). It is noted, however, that while the networks provide 'support and conversation', i.e. constitute communities or wholes, they do not need to be entities that act in a dominant manner themselves, i.e. according to 
one or more objectives that dominate all participant's objectives. The result of implementing individual instructions thus is limited to interactions that 'enhance' what each participant is able to do and that increase their 'resilience' to deal with internal or external threats (p. 23, for example the threat of participants who 'leave or move on'). In other words, the increased resilience helps individuals to survive rather than the networks (and may eventually, as Capra notes, even guarantee the 'survival of humanity'; p. 29). Networks are expected to show a 'dynamic balance' (p. 28) between individual contributions, i.e. one that reduces the risk that dominant activities emerge (for example the formulation of 'collective welfare' as something individually desirable). In other words, individuals can be expected to remain 'interdependent' (so a strict subject and object separation is resisted; p. 24). This emphasises that sustainable networks depend on 'diversity' ( $p$. 25). If all participants would be the same (e.g. as rational decision makers), the resources they contribute would be the same and hence limited, so their interaction would not increase resilience. In other words, high diversity allows networks to show 'antifragility' (Taleb, 2010), while a lack of diversity makes them 'fragile' and easy to disrupt. Teaching the instructions can thus help students to acquire the habit of supporting 'cyclical' relations between individuals so each depends on what others do and hence will wish to avoid mutual 'waste' (p. 25, 26). Such contextual knowledge or instructional research helps in the formation of sustainable enterprises which create capital beyond the finiancial realm-such as territorial capital. Lakshmi, De Zeeuw, Vahl \& Vilalta-perdomo (2015) provide an example of research principles based on praxis of four instructions to develop mutual resources (i.e. territorial capital). They are: a) bring members together; b) select and develop strategies to maintain interactions; c) modify those instructions to increase individual competence; and d) increase the resilience of the interactions so participants may leave or enter, including people from other groups. The authors note that (methodological) instructions to increase the quality of these (participant) instructions are part of the latter, which makes their implementation self-organising. It is noteworthy that instructions relate to principles of behaviour-not rules as it is impossible to set out instructions for every scenario.

This kind of approach as well as the idea behind it (Capra, 2005) is exemplified also by the paradigmatic traps that are inherent to studies based on a strict distinction between subject and object. Other examples were collected by Ostrom (2010), a Nobel Prize winner for Economics, who studied sustainable communities. She emphasises that the diversity of norms people develop in varied settings should be accommodated rather than dominated. Studying communities that aim to maintain fisheries as well as woods as collective goods, she concludes that they are the more sustainable the more high quality participant instructions can be developed. Sustainable communities have to have complex, social and interactive norms. Even so some non-conformist behaviour may be necessary, however, as institutional rules and property rights do not by themselves generate sustainable societies. So long as individuals exercise their free will in the knowledge of interdependence of communities, such non-conformist behaviour will lend flexibility to the communities instead of a rigid structure. The author uses the concept of polycentrism to refer to the co-existence of many people living together with different objectives and experiences. Cooperation and interaction rather than competition ensure that polycentric social systems survive. Ostrom (2010) refutes the notion that a supreme government is required to do so. Like Capra (2005), she emphasises the importance of using models and theories as constraints on individual behaviour rather than as descriptions of its content. Her work provides another stimulus, like Capra's, to develop finance curricula so student contributions become less socially destructive.

As interactions are linked to humans, it is important to realise that institutional and individual greed (Gekkos) and hunger for power are rooted in the constraints they provide rather than in individual genes. Social enterprises and community finance, crowd funding and financing of cooperatives provide powerful examples of how individuals support each othereven when they show non-conformist behaviour in terms of traditional course content. In some countries, a skill-set of this kind appears to be advised already. Wende (2014) explores drivers like the above for liberal arts education from an epistemological, economic and a social- moral point of view for a world-class university in an era of globalisation. These and other examples suggest that it will indeed be worthwhile to transform teaching to include a different kind of knowledge and a different kind of research.

Instead of commencing with MFT as the paradigm, one might start with creating interactions that develop to increase their own sustainability, following Capra's idea. Next one might use the result as a means of modelling social and sustainable markets and businesses. Subsequently, one might introduce the idea that human interactions change the structure and pattern of relationships. These and similar activities can be expected to help develop an ethical, long term focus and to answer questions such as: when markets do not work, what other alternatives can be used? Such questioning could be extended to the financing of public goods and public sector organisations and to the measurement of added value. One example would be the cost of capital, which is currently regarded as the weighted sum of costs of shareholders and lenders, but could be widened to include stakeholders and a social environment to gauge long-term rather than short-term returns.

\section{Discussion and conclusion}

Existing curricula for finance were argued to be relatively insular and artificially constructed, mainly due to their focus on a purely technical toolset. A old style text book approach would appear to be modelling a financial manager along with financial resources and real resources to generate wealth for shareholders. The model is piece-meal and abstracts from values and human interactions. This creates the freedom to both use and misuse the results and neglects the possibility that these may determine how the results change. A cycle of increasing misuse (e.g. increasing inequality of wealth, increasing tax evasion) becomes possible thereby that does not seem to be compensated by the effects of a cycle of increasing use. Both 
possibilities exclude reaching balances that the participants choose themselves, as individuals, rather than having these imposed upon them. Including this experience in teaching would lead to the kind of debate and logical reasoning that seems essential in a pedagogical tool-set. There may be several reasons that this does not happen, but the argument in the paper is that it is may be due to the privatisation of higher education that has encouraged "tangible" and technique laden courses that "sell" better than those which offer a value-oriented stance and require more complex studies. Hitching the offerings to exemptions from professional accounting bodies "brands" courses and offers greater legitimacy and social power-but does not support students to contribute to society. The result is that instead of a differentiation of offerings, rather similar educational products have evolved that are heavy on technique and singular in their use of paradigm. Keasey \& Hudson (2007) provide another explanation: economists prefer to maintain the subject's momentum and hegemony by creating new puzzles from data. The judgement presented in this paper is that there are enough new puzzles (or black swans) to realise that the old approch is not working. A third reason may be related to changes in the overall system, i.e. the way society is focussing on knowing of things rather than values.

A number of suggestions for improvement have been proposed in this paper. These include taking into account the processes that human interactions make possible, rather than only the structures and patterns of social systems treated as non-living. While negative black swans may not be predictable, resilience can be inculcated by searching for sustainable interactions.

As agents of change, universities are expected to positively shape new generations and act as a "conscience to the profession" (Lorsch, Khurana, \& Lo, 2008; Podolny et al., 2009). The financial sector has suffered its worst crisis since living memory and has not fully recovered since 2008. This has led to many calls for reform (Carney, 2014; Gendron \& SmithLacroix, 2013; Sullivan, 2009). In this paper the salient features of the finance curriculum in UK universities are described. It is argued that they are largely similar and based on MFT. Relevant literature is presented to show that MFT is dated and relies on technical neoclassical models rather than on the empirical inclusion of the social medium and the use of a sustainable lens. Capra (2005) is introduced as a possibility for improvement.

The current crisis has resurrected issues relating to the success of MFT. Some of them were raised almost thirty years ago by Bettis (1983) who questioned the way finance theory sits alongside other subjects such as corporate strategy and public policy. It would appear that MFT has perpetuated models that benefit only finance researchers and have limited employability at best and erroneous repercussions at worst when put to a practical test. The past thirty years have witnessed governments, businesses and even public organisations bowing to ideologies and their technical models that focus on maximising purely financial values over social and environmental ones, without providing a sufficient understanding of the relevance of the latter. The result has proved unstable and dangerous and has been shown to lead to catastrophic consequences (Reinhart \& Rogoff, 2009). Financial practices have initiated a widening between the incomes of the wealthy and the poor, reaching levels that preceded for example the crashes of 1929 and 2008, and to serious instabilities in public programmes of pensions, health and education (Carney, 2014).

\section{References}

ACCA (2015). Retrieved from http://www.accaglobal.com/uk/en.html Accessed 02.05.15.

Akerlof, G. A., \& Shiller, R. J. (2010). Animal spirits: how human psychology drives the economy, and why it matters for global capitalism. Princeton: Princeton University Press.

Andersson, T., Lee, E., Theodosopoulos, G., Yin, Y. P., \& Haslam, C. (2014). Accounting for the financialized UK and US national business model. Critical Perspectives on Accounting, 25, 78-91. http://dx.doi.org/10.1016/j.cpa.2012.10.006.

Arnold, G. (2013). Corporate financial management, Fifth ed. Pearson.

Arnott, R. D. (2005). Whither finance theory? Financial Analysts Journal, 61(1), 12-14.

Atrill, P. (2009). Financial management for decision makers. U.K: Pearson.

BBC, (2012). FSA calls for tighter laws against failing bankers. Retrieved from http://www.bbc.co.uk/news/business-18663470 U.K.

BBC 2, (2013). OU on the bankers U.K.

Baddeley, M. (2013). Behavioural economics and finance. Routledge.

Bell, B., \& Reenen, J. (2014). Bankers and their bonuses. Economic Journal, 124(574), F1-F21. http://dx.doi.org/10.1111/ecoj.12101.

Bennis, W. G., \& O'Toole, J. (2005). How business schools lost their way. Harvard Business Review, 83(5), 96-104.

Bernardi, R., Melton, M., Roberts, S., \& Bean, D. (2008). Fostering ethics research: an analysis of the accounting, finance and marketing disciplines. Journal of Business Ethics, 82(1), 157-170. http://dx.doi.org/10.1007/s10551-007-9569-z.

Bettis, R. A. (1983). Modern financial theory, corporate strategy, and public policy: three conundrums. Academy of Management Review, 8(3), 406-415. http:// dx.doi.org/10.5465/AMR.1983.4284379.

Beunza, D., \& Stark, D. (2012). Seeing through the eyes of others: dissonance within and across trading rooms. In C. Knorr, Karin, \& A. Preda (Eds.), Oxford handbook of the sociology of finance. Oxford handbooks in business and management (pp. 203-222).Oxford: Oxford University Press.

Black, F., \& Scholes, M. (1973). The pricing of options and corporate liabilities. The Journal of Political Economy637-654.

Blundell-Wignall, A., Atkinson, P., \& Se, H. L. (2009). The current financial crisis: causes and policy issues. OECD Journal: Financial Market Trends, 2008(2), 1131.

Boatright, J. R. (2010). Finance ethics: critical issues in theory and practice. John Wiley \& Sons.

Bodie, Z., Kane, A., \& Marcus, A. J. (2013). Investments, 10th ed. McGraw-Hill/Irwin Series in Finance, Insurance, and Real Estates.

Bogle, J. C. (2008). Black Monday and black swans. Financial Analysts Journal, 64(2), 30-40.

Brealey, R. A., \& Myers, S. C. (2003). Efficient markets, Principles of corporate finance. 7th ed. Boston: McGraw-Hill/Irwin (Chapter 13).

Brealey, R., Myers, S., \& Allen, F. (2013). Principles of corporate finance, 11th ed. UK: McGraw-Hill Education (UK) Ltd.

Brown, R., \& Carasso, H. (2013). Everything for sale? The marketisation of UK higher education. Abingdon,Oxon: Routledge.

Browne, J., (2010). Securing a sustainable future for higher education: An independent review of higher education funding and student finance. UCL Institute of Education, Retreived from http://dera.ioe.ac.uk/11444/ Accessed 02.05.15.

Caldentey, E. P., \& Vernengo, M. (2010). Modern finance: methodology and the global crisis. Real-World Economics Review, 52, 69-81. 
Capra, F. (2005). Speaking nature's language: principles for sustainability. In M. K. Stone, \& Z. Barlow (Eds.), Ecological literacy (pp. 18-29).San Franciso: Sierra Club Books.

Carney, M. (2014). Inclusive capitalism: creating a sense of the systemic. Bank of England.

Christian, A., \& Yanis, V. (2006). What is neoclassical economics? The three axioms responsible for its theoretical oeuvre, practical irrelevance and, thus, Discursive power. Panoeconomicus5.

Clark, J., \& Schug, M. C. (2010). Morality of markets. In M. C. Schug, \& W. C. Wood (Eds.), Teaching economics in troubled times: theory and practice for secondary social studies (pp. 79-94).New York: Routledge.

Cohen, A. J., \& Elster, J. (1985). Explaining technical change. A case study in the philosophy of science. Journal of Economic Issues, $19(1), 263-265$.

Coleman, L. (2014). Why finance theory fails to survive contact with the real world: a fund manager perspective. Critical Perspectives on Accounting, 25(3), 226-236. http://dx.doi.org/10.1016/j.cpa.2013.02.001.

Dempsey, M. (2013). The capital asset pricing model (CAPM): the history of a failed revolutionary idea in finance? Abacus, 49, 7-23. http://dx.doi.org/10.1111/ j.1467-6281.2012.00379.x.

Dobusch, L., \& Kapeller, J. (2012). Heterodox united vs. mainstream city? Sketching a framework for interested pluralism in economics. Journal of Economic Issues, 46(4), 1035-1057. http://dx.doi.org/10.2753/JEI0021-3624460410.

Dowd, K. (2004). Qualitative dimensions in finance and risk management research. In C. G. Humphrey, \& W. J. Lee (Eds.), The real life guide to accounting research: a behind-the-scenes view of using qualitative research methodsAmsterdam: Elsevier.

Fama, E. F., \& French, K. R. (2004). The capital asset pricing model: theory and evidence. Journal of Economic Perspectives, $18(3), 25-46$.

Fehr, E., \& Fischbacher, U. (2002). Why social preferences matter-the impact of non-selfish motives on competition, cooperation and incentives. Economic Journal, 112(478), C1.

Ferguson, R. W. J. (2011). Long term financial security. In G. Rosenfeld, J. W. Lorsch, \& K. Khurana (Eds.), Challenges to business in twenty-first centuryCambridge, MA: American Academy of Arts and Sciences.

Ferraro, F., Pfeffer, J., \& Sutton, R. I. (2005). Economics language and assumptions: how theories can become self-fulfilling. Academy of Management Review, 30(1), 8-24. http://dx.doi.org/10.5465/AMR.2005.15281412.

Findlay, M. C., \& Williams, E. E. (2000). A fresh look at the efficient market hypothesis: How the intellectual history of finance encouraged a real 'fraud-onthe-market'. Journal of Post Keynesian Economics, 23(2), 181.

Findlay, M. C. (1987). Toward a positive theory of corporate financial policy. Abacus, 23(2), 107-121.

Fox, J. (2010). Are finance professors and their theories to blame for the financial crisis? CFA Institute Conference Proceedings Quarterly, 27(2), 4.

Frankfurter, G. M., \& McGoun, E. G. (1999). Ideology and the theory of financial economics. Journal of Economic Behavior and Organization, 39, 159-177. http:// dx.doi.org/10.1016/S0167-2681(99) 00030-X.

Fromlet, H. (2001). Behavioral finance-theory and practical application. Business Economics, 36(3), 63.

Güth, W. (2010). Satisficing and (un) bounded rationality-a formal definition and its experimental validity. Journal of Economic Behavior E Organization, 73 (3), 308-316.

Gendron, Y., \& Smith-Lacroix, J. (2013). The global financial crisis: essay on the possibility of substantive change in the discipline of finance. Critical Perspectives on Accounting., 30, 83-101.

Ghoshal, S., \& Moran, P. (1996). Bad for practice: a critique of the transaction cost theory. Academy of Management Review, 21(1), 13-47. http://dx.doi.org/ 10.5465/AMR.1996.9602161563.

Ghoshal, S. (2005). Bad management theories are destroying good management practices. Academy of Management Learning E' Education, 4(1), 75-91. http:// dx.doi.org/10.5465/AMLE.2005.16132558.

Giacalone, R. A., \& Thompson, K. R. (2006). Business ethics and social responsibility education: Shifting the worldview. Academy of Management Learning E Education, 5(3), 266-277. http://dx.doi.org/10.5465/AMLE.2006.22697016.

Giddens, A., \& Dallmayr, F. R. (1982). Profiles and critiques in social theory. London: Macmillan.

Gray, R., \& Collison, D. (2002). Cant see the wood for the trees, cant see the trees for the numbers? Accounting education, sustainability and the public interest. Critical Perspectives on Accounting, 13(5), 797-836.

Haug, E. G., \& Taleb, N. N. (2011). Option traders use (very) sophisticated heuristics, never the Black-Scholes-Merton formula. Journal of Economic Behavior E Organization, 77(2), 97-106.

Hillier, D., Grinblatt, M., \& Titman, S. (2011). Financial management and corporate strategy, 2nd ed. U.K: McGraw-Hill Higher Education.

Hillier, D. J., Ross, S. A., Westerfield, R. W., Jaffe, J., \& Jordan, B. D. (2012). Corporate finance: European edition, 2nd ed. Global McGraw-Hill Education (UK) Ltd..

Hines, R. D. (1989). The sociopolitical paradigm in financial accounting research. Accounting, Auditing \& Accountability Journal, 2(1), 52-76.

Hopwood, A. G. (2009). The economic crisis and accounting: implications for the research communit. Accounting. Organizations and Society, 34(6-7), 797802.

ICAEW, (2015). Retrieved from http://www.icaew.com/ /media/d40db4de82a34b1392ad975afe8f2a8f.ashx Accessed 05.05.15.

Jensen, M. C. (2002). Value maximization, stakeholder theory, and the corporate objective function. Business Ethics Quarterly, 12(2), 235-256.

Johnstone, D. J. (2013). The CAPM debate and the logic and philosophy of finance. Abacus, 49, 1-6. http://dx.doi.org/10.1111/j.1467-6281.2012.00378.x.

Jones, T. M., \& Felps, W. (2013). Shareholder wealth maximization and social welfare: a utilitarian critique. Business Ethics Quarterly, 23(2), 207-238. http:// dx.doi.org/10.5840/beq201323215.

Jorion, P. (2009). Risk management lessons from the credit crisis. European Financial Management, 15(5), 923-933. http://dx.doi.org/10.1111/j.1468036X.2009.00507.x.

Keasey, K., \& Hudson, R. (2007). Finance theory: a house without windows. Critical Perspectives on Accounting, 18(8), 932-951.

Killingley, P. (2012). The global higher education sector to 2020: a landscape of change and challenges. Business schools seizing the future. London: Association of Business Schools13-16.

Krugman, P. (2002). Greed is bad. The New York Times June 4.

Kuhn, T. S. (1962). The structure of scientific revolutions. Chicago: University of Chicago Press (1962 (50th Anniversary Edition: 2012$)$ ).

Laing, A. (2012). Welcome foreward. Business schools seizing the future. London: Association of Business Schoolsiii.

Lakshmi, G., De Zeeuw, G., Vahl, M., \& Vilalta-perdomo, E. L. (2015). Making friends with windmills: building territorial capital. ACRN Oxford Journal of Finance and Risk Perspectives, 4(4), 100-108.

Lakshmi, G. (2013). An exploratory study on cognitive skills and topics focused in learning objectives of finance modules: a UK perspective. Accounting Education, 22(3), 233-247.

Lazear, E. P. (1999). Economic Imperialism. NBER working paper No. 7300. MA: Cambridge.

Lee, F. S., Pham, X., \& Gu, G. (2013). The UK research assessment exercise and the narrowing of UK economics. Cambridge Journal of Economics, 37(4), 693-717.

Lee, F. S. (2012). Heterodox economics and its critics. Review of Political Economy, 24(2), 337-351. http://dx.doi.org/10.1080/09538259.2012.664360.

London School of Economics (online), (2015).

Lorsch, J., Khurana, R., \& Lo, A. (2008). Financial crisis: blame B-schools. Bloomberg Businessweek.

MacKenzie, D. (2005). Opening the black boxes of global finance. Review of International Political Economy, 12(4), 555-576.

Maio, M. D. (2013). Are mainstream and heterodox economists different? An empirical analysis. American Journal of Economics and Sociology, 72(5), 13151348. http://dx.doi.org/10.1111/ajes.12044.

Marsh, T. A., \& Merton, R. C. (1986). Dividend variability and variance bounds tests for the rationality of stock market prices. The American Economic Review, 76, 483-498.

Mathews, M. R. (2001). Whither (or wither) accounting education in the new millennium. Accounting Forum, $25(4), 380$.

Merton, R. C. (2002). Future possibilities in finance theory and finance practice. Mathematical Finance-Bachelier Congress $200047-73$. 
Miller, M. H. (2000). The history of finance: an eyewitness account. Journal of Applied Corporate Finance, 13(2), 8-14.

Minsky, H. P. (1977). The financial instability hypothesis: an interpretation of Keynes and an alternative to standard. Challenge, 20(1), 20-28.

Mishkin, F. S., \& Strahan, P. E. (1999). What will technology do to financial structure? NBER working paper No. 6892. MA: Cambridge.

Myrdal, G. (1972). How scientific are the social sciences. Journal of Social Issues, 28, 151-170.

Ostrom, E. (2010). Beyond markets and states: polycentric governance of complex economic systems. American Economic Review, 100, 641-672.

Pan, P., \& Perera, H. (2012). Market relevance of university accounting programs: evidence from Australia. Accounting Forum, 36, 91-108. http://dx.doi.org/ 10.1016/j.accfor.2011.11.001.

Papadimitriou, D. B., \& Wray, L. R. (1999). Minsky's analysis of financial capitalism. The Jerome Levy Economics Institute working paper, 275, New York: Levy Economics Institute.

Perri, F. S., \& Brody, R. G. (2011). Birds of the same feather: the dangers of affinity fraud. Journal of Forensic Studies in Accounting E Business, 3(1), 33-46. Podolny, J. M., Kester, W. C., Kerr, S., Sutton, R. I., Kaplan, S., Martin, R., et al. (2009). Are business schools to blame? Harvard Business Review, 87(6), 106-108. QAAa, (2007). Subject Benchmarks: Finance, http://www.qaa.ac.uk/academicinfrastructure/benchmark/statements/Finance.as, Retrieved 24/2/2014.

QAAb, (2007). Subject Benchmarks: Accounting, http://www.qaa.ac.uk/Publications/InformationAndGuidance/Pages/Subject-benchmark-statementAccounting.aspx, Retrieved 24/2/2014.

QAAc, (2007). Subject Benchmarks: Economics, http://www.qaa.ac.uk/Publications/InformationAndGuidance/Pages/Subject-benchmark-statementEconomics.aspx, Retrieved 24/2/2014.

Reinhart, C. M., \& Rogoff, K. (2009). This time is different: eight centuries of financial folly. Princeton, New Jersey: Princeton University Press.

Ross, S. A. (1987). The interrelations of finance and economics: theoretical perspectives. The American Economic Review29-34.

Ross, S. A. (2009). Neoclassical finance. Princeton, New Jersey: Princeton University Press.

Russell Group, (2014). About us. Retrieved from http://www.russellgroup.ac.uk/about-russell-group/, Accessed 02.04.15.

Saito, A. T., Savoia, J. R. F. \& Famá, R. (2013). Financial theory evolution. International Journal of Education and Research, 1(4), 1-18.

Scholes, M. S. (1996). Global financial markets, derivative securities, and systemic risks. Journal of Risk and Uncertainty, 12(2-3), 271-286.

Sen, A. K. (1977). Rational fools: a critique of the behavioral foundations of economic theory. Philosophy E Public Affairs317-344.

Sikka, P. (2010). Smoke and mirrors: corporate social responsibility and tax avoidance. Accounting Forum, 34(3-4), 153-168. http://dx.doi.org/10.1016/j. accfor.2010.05.002.

Sikka, P. (2015). The hand of accounting and accountancy firms in deepening income and wealth inequalities and the economic crisis: some evidence. Critical Perspectives on Accounting, 30, 46-62.

Sinclair, P., Spier, G., \& Skinner, T. (2008). Bonuses, credit rating agencies and the credit crunch. University of Birmingham.

Sinclair, T. J. (2003). Global monitor. New Political Economy, 8(1), 147-161.

Soufian, M., Forbes, W., \& Hudson, R. (2013). Adapting financial rationality: is a new paradigm emerging? Critical Perspectives on Accounting. http://dx.doi. org/10.1016/j.cpa.2013.08.009.

Sullivan, R. N. (2009). Markets in crisis. Financial Analysts Journal, 65(1), 17-24.

Taleb, N. N. (2010). The black swan: the impact of the highly improbable fragility. New York: Random House LLC.

Taleb, N. N. (2015). Silent risk, Technical incerto: lecture notes on probability, Vol. 1, Descartes Publishing.

Thaler, R. H. (2000). From homo economicus to homo sapiens. American Economic Association.

The Guardian (online), (2015). QS world university rankings 2014: top 200. Retrieved from http://www.theguardian.com/higher-education-network/nginteractive/2014/sep/16/-sp-qs-world-university-rankings-2014 Accessed 02.05.15.

The Guardian (online), (2015). University guide 2015: League Table for accounting and finance. Retrieved from http://www.theguardian.com/education/nginteractive/2014/jun/03/university-guide-2015-league-table-for-accounting-and-finance, accessed on 02.05.15.

Thomsett, M. C. (2013). Options for risk-free portfolios: profiting with dividend collar strategies. Palgrave Macmillan.

Tinker, A. M., Merino, B. D., \& Neimark, M. D. (1982). The normative origins of positive theories: ideology and accounting though. Accounting, Organizations and Society, 7(2), 167-200.

UCAS, (2013). (Online) UCAS.com Accessed 04.05.13.

UCAS, (2015). (Online) UCAS.com, accessed 02.05.15.

US Securities \& Exchange Commission, (2013). (Online) Insider Trading Cases, Retrieved from http://www.sec.gov/spotlight/insidertrading/cases.shtm, accessed 02.05.13.

University of Birmingham (online), (2015). Bsc accounting and finance. Retrieved from http://www.birmingham.ac.uk/undergraduate/courses/business/ accounting-finance.asp, accessed 02.05.15.

University of Bristol (online), (2015). School of economics, finance and management; undergraduate courses. Retrieved from http://www.bristol.ac.uk/efm/ courses/undergraduate/programmes/, Accessed 02.05.15.

University of Essex (online), (2015). BSc accounting and finance. Retrieved from http://www.essex.ac.uk/coursefinder/course_details.aspx?course=BSC + N420 Accessed 02.05.15.

University of Exeter (online), (2015). BA accounting and finance. Retrieved from Accessed 02.05.15.

University of Leeds (online), (2015). Bsc accounting and finance. Retrieved from http://business.leeds.ac.uk/undergraduate/bsc-accounting-and-finance/ Accessed 02.05.15.

University of Lincoln (online), (2015). BA (hons) accounting and finance. Retrieved from http://www.lincoln.ac.uk/home/course/accfinub/ Accessed 02.05.15.

University of Newcastle (online), (2015). Accounting and finance BA honours. Retrieved from http://www.ncl.ac.uk/undergraduate/degrees/n400/ courseoverview/ Accessed 02.05.15.

University of Sheffield (online), (2015). BA accounting and financial management. Retrieved from https://www.google.co.uk/search?q=University+of +Sheffield\&ie=utf-8\&oe=utf-8\&gws_rd=cr\&ei=ODhbVcauDYGUsAGUtoCwBQ\#q=university+of+sheffield+accounting+and+finance Accessed 02.05.15.

University of Swansea (online), (2015). Bsc accounting and finance. Retrieved from http://www.swansea.ac.uk/undergraduate/courses/som/ bscaccountingandfinance/ Accessed 02.05.15.

von Hayek, F. A. (1989). The pretence of knowledge. The American Economic Review, 79(6), 3-7.

Vollmer, H., Mennicken, A., \& Preda, A. (2009). Tracking the numbers: across accounting and finance, organizations and market. Accounting, Organizations and Society, 34(5), 619-637.

Wall Street, (1987). Film directed by Oliver Stone, USA : 20th Century Fox.

Wang, L., Malhotra, D., \& Murnighan, J. K. (2011). Economics education and greed. Academy of Management Learning and Education, 10(4), 643-660. http://dx. doi.org/10.5465/amle.2009.0185.

Wende, M. V. D. (2014). Trends towards global excellence in undergraduate education: taking the liberal arts experience into the 21st century. Dead Sea Discoveries, 21(1), 289-307. http://dx.doi.org/10.1163/22125868-12340025. 